\title{
The current state of bioeconomy in Poland
}

\author{
Ewa Woźniak¹ and Tomasz Twardowski2 ${ }^{\varpi}$ \\ 1Faculty of Geographical and Geological Sciences of Adam Mickiewicz University, Institute of Socio-Economic Geography and Spatial Manage- \\ ment, Poznań, Poland; IInstitute of Bioorganic Chemistry Polish Academy of Sciences, Poznań, Poland
}

\begin{abstract}
Conversion of scientific achievements to market a product is a key issue and the best description of significance of science for society. In the case of experts in the natural sciences in Poland, we observe a high intellectual potential of researchers and several scientific discoveries. However, Polish inventions are very rarely available on the market and the number of national and international patent applications done by Polish scientists is very limited. For the development of bioeconomy, the progress in biotechnology is critical.
\end{abstract}

Key words: bioeconomy, biotechnology, bioregion, GMO

Received: 07 June, 2016; revised: 24 June, 2016; accepted: 01 July, 2016; available on-line: 02 November, 2016

\section{INTRODUCTION}

Bioeconomy is usually defined as use of renewable biological resources to produce food, biomaterials and energy; often, in everyday language, we use the following definition: conversion of biomass (usually the waste) into value-added products using biological methods. In another words, this is a unique perspective and multidimensional challenge towards new resources of food, energy, materials, pharmaceuticals and many more. We can also present these opportunities as food security and energy security, environmental protection and innovative industry.

Bioeconomy is already several years old. Its development all over the world has been very similar, however, it is run in a very different way. The socioeconomic background and expectations, as well as regulatory procedures, are quite different in the European Union and in the Americas.

The sustainable exploitation of our natural resources needs appropriate tools. Very often, we think (and say) that the old continent gives rise to many innovative methods later on developed and commercialized in the new economies, from the United States to South Africa. It is worth to remember that the roots of many genetic engineering techniques are in Europe, but the economic development was done in the other continents. In this issue of Acta Biochimica Polonica, several techniques and methods critical for the future development of bioeconomy are described. In this paper, we would like to focus on the current status of modern biotechniques in the economy sector of Poland.

The innovation capacity and great research capabilities are focused in our country on several areas: first, the basic research per se, next - agriculture and the food/feed production, medicine (including pharmacy and diagnostics as well as veterinary sciences), the environmental protection (including waste utilization), energy production from biomass, biogas and biofuels, biomaterials, and molecular bases of biotechnology. There are several indicators that the RNA technology will in general give a brand new input to biotechnology. A separate package of issues is related to legal and socioeconomic issues. The majority of research and industrial activities is supported by the state; participation of the private sector is unfortunately relatively small. In the major academic centers in Poland, several bio - "clusters" and "parks", dedicated to the transfer of academic achievements to industry, have been established. In order to establish this structure, the primary investment was made by the state; in next step, the research money used for academic grants and projects has to be converted into business: startup and innovative companies.

\section{LEGAL AND SOCIOECONOMIC ISSUES}

Public perception of biotechnology is recognized as a factor of critical importance for further development of any innovative technology. Public acceptance influences the economic value of innovative products, services and technologies (Małyska 2011, Małyska 2013). Currently, the public opposition in Poland (Pentor, 2012), as well as in the European Union, restrains the process of commercial applications and development of biotechnology, particularly in the case of agriculture. Surprisingly, the opposition in the case of applied genetic engineering for medicine, pharmacy and cosmetics is significantly less important or almost nonexistent. The government's Framework Position paper on GMO declared Poland as a "GMO-free zone" (Position Paper on GMO, 2011). Following this, the recent Polish legislation does not support the research of the industrial applications of GMOs (amendment of the legal act of GMO, 2015). The international scientific community presented high expectations concerning the potential of genetic engineering in many reports, and one of the very best and most representative is "Planting the Future" ("Planting the Future", 2013). Polish biotechnologists expressed their dissatisfaction and worries about the future of biotechnology in several position papers, the best represented by a position paper concerning biotechnology legislation in Poland (Position Paper, 2015).

In Poland, there is no strategic document dedicated to bioeconomy. Issues related to the development of bioeconomy are incorporated in three integrated strategies, which are included in the implementation of the Medi-

e-mail: twardows@ibch.poznan.pl 
um-Term Strategy for the Development of the Country. This document defines the development goals for Poland until 2020. It is focused on the increase of capacity in three areas: competitive and innovative economy, effective and robust state, showing the differences in development of the regions. The other strategies, which refer to bioeconomy, are: Strategy for Innovation and Efficiency of the Economy, Strategy of Energy Safety and Environment and Strategy for Sustainable Development of Agriculture, Rural Areas and Fisheries (Gołębiewski, 2015). The roles of biotechnology in the progress and in improving services in medicine, pharmacy (particularly in the production of new, innovative drugs) and in the protection of the environment are stressed.

In the strategy published in 2011, the European Commission has set for itself an objective of long-term development of a competitive, resource-efficient and lowcarbon economy until 2050, and the concept of green economy was integrated into the overall economic policy framework of the EU. In addition to this strategy, many EU Member States have developed their national bioeconomy strategies.

Table 1. Bio-clusters and bio-parks in Poland (2014)

\begin{tabular}{|c|c|c|c|c|}
\hline No. & Name & Location (voivodeship-city) & An example of companies & Coordinator \\
\hline 1. & Nutribiomed Cluster & Lower Silesia-Wrocław & $\begin{array}{l}\text { - Farmaceutyczny Zakład } \\
\text { Naukowo-Produkcyjny „Biochefa”; } \\
\text { - P.W. „Futurum” } \\
\text { - Technox }\end{array}$ & Wrocław Technology Park \\
\hline 2. & BioEcoChem Cluster & Pomerania-Gdańsk & $\begin{array}{l}\text { - Zakłady Farmaceutyczne } \\
\text { POLPHAEMA } \\
\text { - Lipopharm.pl } \\
\text { - Blirt } \\
\text { - A\&A Biotechnology }\end{array}$ & $\begin{array}{l}\text { Gdańsk University of } \\
\text { Technology, } \\
\text { BioBaltica }\end{array}$ \\
\hline 3. & $\begin{array}{l}\text { West Pomeranian Chemical } \\
\text { Cluster "Green Chemistry" }\end{array}$ & West Pomerania -Szczecin & $\begin{array}{l}\text { - Fosfan } \\
\text { - Zakłady Chemiczne Police } \\
\text { - Kemipol }\end{array}$ & $\begin{array}{l}\text { West Pomeranian Chemi- } \\
\text { cal Cluster }\end{array}$ \\
\hline 4. & $\begin{array}{l}\text { Eco-Energetic Cluster EEl- } \\
\text { Energy, Ecology, Innovation }\end{array}$ & Lower Silesia-Wrocław & $\begin{array}{l}\text { - Biotransformation Department, } \\
\text { University of Wrocław }\end{array}$ & CEDRES Foundation \\
\hline 5. & Bioenergy for the Region & Łódź - Łódź & - Trimen Chemicals & CBI Pro-Academy \\
\hline 6. & Life Science & Lesser Poland-Kraków & $\begin{array}{l}\text { - IBSS BIOMED } \\
\text { - Adamed } \\
\text { - Afisen } \\
\text { - Biopharge PharmA } \\
\text { - Selvita S.A. }\end{array}$ & $\begin{array}{l}\text { Jagiellonian Center of } \\
\text { Innovation }\end{array}$ \\
\hline 7. & Organic Food Valley & Lublin-Lublin & $\begin{array}{l}\text { - Owocowe Smaki } \\
\text { - Barwy Zdrowia }\end{array}$ & $\begin{array}{l}\text { The Institute of Soil Scien- } \\
\text { ce and Plant Cultivation } \\
\text { (IUNG) }\end{array}$ \\
\hline 8. & Food Cluster & Greater Poland-Kalisz & $\begin{array}{l}\text { - WPPH Elena Import-Export } \\
\text { - Lazur Spółdzielnia Mleczarska } \\
\text { - Ceko Sp. z o.o }\end{array}$ & Private \\
\hline 9. & $\begin{array}{l}\text { Biotechnology Cluster BIO- } \\
\text { PARK }\end{array}$ & Pomerania - Gdańsk & $\begin{array}{l}\text { - Biomax } \\
\text { - Nutri Pharmax }\end{array}$ & $\begin{array}{l}\text { Gdansk Science\&Techno- } \\
\text { logy Park }\end{array}$ \\
\hline 10. & $\begin{array}{l}\text { Lublin Medicine-Medical \& } \\
\text { Wellness Cluster }\end{array}$ & Lublin-Lublin & - VitaGenum & $\begin{array}{l}\text { The City of Lublin and } \\
\text { Medical University of } \\
\text { Lublin }\end{array}$ \\
\hline 11. & BTM (BioTechMed) & Masovia-Warszawa & $\begin{array}{l}\text { - Celon Pharma } \\
\text { - TriMen Chemicals }\end{array}$ & Dedicated company \\
\hline 12. & BioNanoPark & Łódz-Łódź & - laboratory services & $\begin{array}{l}\text { Łódzki Regionalny Park } \\
\text { Naukowo-Technologiczny }\end{array}$ \\
\hline 13. & $\begin{array}{l}\text { Gdański Park Naukowo-Tech- } \\
\text { nologiczny (GPN-T) }\end{array}$ & Pomerania - Gdańsk & $\begin{array}{l}\text { - Polpharma } \\
\text { - Blirt }\end{array}$ & $\begin{array}{l}\text { Pomeranian Special Eco- } \\
\text { nomic Zone }\end{array}$ \\
\hline 14. & $\begin{array}{l}\text { Poznan Science and Techno- } \\
\text { logy Park }\end{array}$ & Greater Poland- Poznań & $\begin{array}{l}\text { - DNA Research Center } \\
\text { - Future Synthesis } \\
\text { - PolBiotech Laboratorium }\end{array}$ & $\begin{array}{l}\text { University of Adam Mic- } \\
\text { kiewicz }\end{array}$ \\
\hline 15. & You Nick & Greater Poland- Suchy Las & - Smart Pharma & Private \\
\hline
\end{tabular}

Source: http://www.pi.gov.pl/

\section{BIO-CLUSTERS AND BIO-PARKS}

Biocluster is a name given to any geographically limited concentration of the following organizations (European Commission, 2008):

- institutions of higher education with specializations in the life sciences;

- institutes (public or private) carrying out research in the life sciences or applying biotechnology to their research work;

- companies focusing on the life sciences by either carrying out R\&D in the life sciences, or applying biotechnology to their R\&D or production, or offering services to the life sciences firms, or applying biotechnology to their services.

There are several functioning bio-clusters and bioparks in Poland (Table 1). Most of them are associated with the medical and pharmaceutical sectors.

A bioregion can (but not need) contain one or several bio-clusters and biotech/bioscience/life sciences parks, which are supposed to interact in order to enhance their efficiency. A bioregion may even reach across political

Source: http://www.pi.gov.pl/ 
Table 2. Technology fields in Poland in 2014-2015

\begin{tabular}{|c|c|c|c|}
\hline Technology field & 2014 & 2015 & $\begin{array}{c}\text { Growth: } \\
2015 / 2014\end{array}$ \\
\hline Fine organic chemistry & 21 & 43 & $104.8 \%$ \\
\hline Civil engineering & 29 & 39 & $34.5 \%$ \\
\hline Measurements & 22 & 35 & $59.1 \%$ \\
\hline Basic materials chemistry & 15 & 30 & $100.0 \%$ \\
\hline Medical technology & 29 & 29 & $0.0 \%$ \\
\hline Computer technology & 27 & 29 & $7.4 \%$ \\
\hline Pharmaceuticals & 9 & 29 & $222.2 \%$ \\
\hline Transport & 19 & 25 & $31.6 \%$ \\
\hline $\begin{array}{l}\text { Electrical machinery, appa- } \\
\text { ratus, energy }\end{array}$ & 22 & 22 & $0.0 \%$ \\
\hline Other special machines & 22 & 22 & $0.0 \%$ \\
\hline Biotechnology & 14 & 21 & $50.0 \%$ \\
\hline Materials, metallurgy & 14 & 21 & $50.0 \%$ \\
\hline Other consumer goods & 17 & 20 & $17.6 \%$ \\
\hline Handling & 8 & 20 & $150.0 \%$ \\
\hline Environmental technology & 8 & 18 & $125.0 \%$ \\
\hline Sub-total & 276 & 403 & $46.0 \%$ \\
\hline All fields & 482 & 568 & $17.8 \%$ \\
\hline
\end{tabular}

Source: EPO

borders. In Europe, there are bioregions with medical, agricultural or industrial biotech companies, research centers, science parks and bio-incubators, universities and various business service providers (European Commission). We can mention the Flanders/Belgium bioregion, Medicon Valley (Denmark/Sweden) and BioValley (Denmark, France, Switzerland) as the biggest and the most efficient bioregions in Europe (European Commission). They create great opportunities to cooperate and attend to more investors and scientists from all around the world.

In the case of new, innovative Polish companies, the most difficult issue is conversion of academic ideas to consumer products, available to lay people. This is the best illustrated through a low number of national and especially international patent applications. Just for illustration: In 2014 the number of biotechnology patent applications and utility model applications filed in the Polish Patent Office by domestic entities amounted to 121 (Polish Patent Office, 2016). According to the data from EPO (European Patent Office) there were 568 patents applications in Poland in 2015 (Table 2). The share of biotechnology patents among all patents in 2015 amounted to $4 \%$, whereas the share of pharmaceutical patent applications accounted for 5\%. Protection of intellectual property rights, commonly known as "patenting", is the very first step to a potential industrial application. Knowledge of the intellectual property law is still very limited within Polish academia and developments of clusters should improve this situation significantly.

\section{INDUSTRIAL BIOTECHNOLOGY}

In Poland, renewable energy sources develop quite rapidly. The renewable sources of energy produced in
2013 account for more than $10 \%$ of the total energy production. They have a limited impact on environmental protection. However, this is significant in terms of public perception and feelings, as well as meeting the directives of the European Commission. Poland is obliged to reach a $15 \%$ share of renewable sources in energy consumption until 2020. This results from the Climate Package. The leading position is held by wind energy. In 2014 , almost $40 \%$ of energy from renewable resources was produced by wind installations, while $22 \%$ was produced by biomass energy. According to the data of the Energy Regulatory Office (URE), there were 278 biogas plants in Poland with a total capacity of 212497 MW, and 38 biomass plants with a total capacity of 1122670 MW (total production was at $6970032 \mathrm{MW}$ ). Biogas and biomass are very important sources of renewable energy. Their share in all power production of energy from renewable resources in Poland equaled to almost $20 \%$. $74 \%$ of biogas plants are using sewage treatment and dump for energy production. On the other hand, 50\% of biomass plants used mixed biomass in their production of energy. Moreover, 36\% of those plants used biomass from forests, agricultural and garden waste in their production (URE, 2015). According to the EBA Biogas Report, in 2014 there were more than 14500 biogas plants in Europe, and their number is still growing. The largest number of biogas plants was in Germany (9035), Italy (1391), Switzerland (620) and France (610).

Biofuels are liquid fuels from a non-fossilized biological origin and also represent a renewable energy resource. Biofuels can be divided into biogasoline and biodiesel, depending on the origin of the material used (Eurostat). Biofuels may also be derived from forestry, agricultural products or municipal wastes, as well as from the agro and food industry. According to URE, in 2014 the quantity of biocomponents produced by all generators amounted to 834990 tons. Most of them (83\%) accounted for esters, and $17 \%$ for bioethanol. The quantity of biocomponents, which were sold by producers in the country, amounted to 508138 tons. The vast majority came from the sale of bioethanol $(96 \%)$. On the other hand, the quantity of biofuels was 46726 tons in 2014. The main biofuel is ester, of which 30648 tons were sold in the country. This makes about $65 \%$ of the total biofuel production in 2014.

Production of bio-ethanol and bio-diesel develops well in Poland, and this issue is supported by the state and the relevant legislation. Similarly, one should recognize the significant usage of modern enzyme technology in the food production.

\section{AGRICULTURAL BIOTECHNOLOGY}

Nowadays, we point out the need for wider use of agriculture not only for food production and to ensure food security, but also to produce biomass as a renewable source of raw materials for the industry of new types of goods and services (Adamowicz, 2014).

In 2013, the domestic compound feed production in Poland was at 9150000 tons. According to the European Manufactures' Federation - FEFAC, 63\% of that feed production referred to the poultry and $21 \%$ to the pigs. The number of compound feed production units was at 106. Larger unit numbers were in Spain (820), Italy (490) and France (295).

Annually, about 2 million tons of soybean meal GM are imported in Poland. This represents 60\% of highprotein raw materials to produce feed. One of the ways 
to become independent of imports of soybean meal might be the development of indigenous sources of protein based on legumes (http://www.portalspozywczy. $\mathrm{pl} /$;.prolegumes.eu). However, this very attractive solution is related to many obstacles. The biggest producer of soybean meal non-GMO is Brazil, that produces about 4-5 million tons each year, $40 \%$ of which are exported to Europe (The Grain and Feed Chamber).

According to Bielecki, Poland is the 8th biggest food exporter in the European Union. This is confirmed by a dynamically increasing export of drinks and food (CSO, 2014). The Polish food industry is also one of the most competitive in the European Union. The produced food that was sold in 2013 amounted to 42 billion EUR (CSO).

We should stress the significant use of the GM products in Poland, like enzymes produced by GM bacteria (proteases, chymosin, etc), necessary for the production of food (e.g. juice and cheese). The production of flowers with extensive use of modern biotech methods is very well developed and profitable. GMOs and GM products (e.g. enzymes) have been in commercial use for about 40 years. We have to point out: no single dangerous accident happened during this period of time. Several well documented reports were published about the food/feed safety, in contrast to not confirmed articles describing potential dangers. On the other hand, we have to mention the urgent need for the development of new, efficient production of food within Europe: the EU (including Poland) is not food secure; domestic production covers about half of our needs. Plant breeding in the EU contributes to various economic, social and environmental values. It is necessary for combating hunger and malnutrition, and improves the world food security situation (HFFA Research Paper).

\section{PHARMACEUTICAL BIOTECHNOLOGY}

In the recent years, the pharmaceutical market in Poland has seen continuous growth, reaching about 22.3 billion PLN (5 billion EUR) in 2011. Poland is ranked not only as the biggest medical/pharmaceutical market in Central Europe, but also as a hub for production and functional activities (PAIiIZ). Foreign investors noticed that Poland is a country with a high level of knowledge and research potential. Companies which produced tra-

Table 3. The largest pharmaceutical companies in Poland (2013)

\begin{tabular}{lll}
\hline No. & Company & Localization \\
\hline 1. & Polpharma & Starogard Gdański \\
\hline 2. & Sanofi-Aventis & Warsaw \\
\hline 3. & Teva Group & Krakow, Kutno \\
\hline 4. & Valeant Pharma & Rzeszów \\
\hline 5. & Sandoz Corp. & Warsaw \\
\hline 6. & GSK Pharma & Poznań \\
\hline 7. & Novartis (including Sandoz) & Stryków \\
\hline 8. & Adamed Group & Pieńków, Pabianice \\
\hdashline 9. & KRKA & Warsaw \\
\hline 10. & Aflofarm & Pabianice \\
\hline 11 & USP Zdrowie & Wrocław \\
\hline 12. & Bayer & Warsaw \\
\hline
\end{tabular}

Source: PAlilZ ditional genetic drugs, like Celon Pharma, and companies which connect biotechnology with pharmaceuticals (Adamed, Blirt) are increasingly focused on the development of new innovative drugs (PAIiIZ). The largest companies in terms of drug sales are: Polpharma, SanofiAventis, Teva and GSK (Table 3). However, we have to stress that no brand new drug was developed in Poland in last 50 years. The most significant success of msodern biotech industry: production of human insulin (named gensulin) by Bioton, is based on a licensed genetic construct; however, Bioton has successfully developed on its own several new technologies dedicated to the production line of gensuline, like purification and application methods.

The Polish pharmaceutical market is dominated by imported drugs. In 2011, the imports volume amounted to 3.66 billion EUR and exports to 1.49 billion PLN (345 million EUR). The major receivers of the Polish medicines are: Germany, Russia and Italy. Foreign investors have the biggest share in the Polish pharmaceutical market. The major countries investing in the pharmaceutical sector are: Germany (Bayer), France (Sanofi-Aventis) and UK (GSK). The pharmaceutical market is quite mature. There are 450 enterprises, which are private foreign companies. Moreover, about 70 companies in Poland operate in the biotechnological sector. A separate issue is the information technology (IT) dedicated to this sector of economy, particularly bioinformatics, pretty well developed in our country.

\section{CONCLUSIONS}

Bioeconomy and biotechnology are characterized by a high intellectual potential of researchers and many interesting scientific discoveries in Poland. However, Polish inventions are very rarely converted into commercial products. We have to take into account the very important factor: the Polish market counts about $38 \mathrm{mln}$ customers. Will we participate in the development and will we collect the effects of innovative biotechniques like RNA technology in Poland? A complicated regulatory framework is slowing down the progress and industrial applications to a significant extent. The EU develops ideas and solutions as to how to modify organisms, e.g. the use of cisgenesis, epigenesis, CRISPR/Cas90 and many more, without the requirement for the excessive legislation. But the transfer of academic ideas to industry is very difficult. Genetic engineering provides unique solutions. However, the genetic engineering is not the only one.

A more sustainable, more prosperous future of the European economy will be called the "Bioeconomy". There are several questions presented in this paper and this is the only way to answer all of them: just do it. And the collection of articles in this issue of Acta Biochimica Polonica is the best answer to show the real potential of our research laboratories. The important issues are cooperation and the transfer of knowledge and technologies from scientific and research units to industrial partners. In this way, we can think about beginnings of the formation of local bioregions in the near future. The Polish pharmaceutical market has an important share in the economy of our country. Evidently, we do have significant achievements in the molecular diagnostics (DNA sequencing) and production of plants in vitro. The next the goal set by the European Commission will be to "make Europe, the most competitive and the most dynamic knowledge-based economy in the world". 


\section{Acknowledgements}

This publication was supported by the Polish Ministry of Science and Higher Education, under the KNOW program.

\section{REFERENCES}

Act of 15 January 2015 on genetically modified organisms and some other acts. Dz.U. 2015 poz. 277

Adamowicz M (2014) European concept of bioeconomy and its bearing on practical use. Economic and Regional Studies, vol. 7, no. 4.

Bielecki S. Bioeconomy in Poland-open opportunities. ERRIN/ERIAFF Joint Inititive - Brussells, March 19-20, 2015

Central Statistical Office of Poland http://stat.gov.pl (retrieved: 09 Mar. 2016)

European Academies Science Advisory Council (2013) EASAC policy report 21: Planting the future: opportunities and challenges for using crop genetic improvement technologies for sustainable agriculture.

European Biogas Association, Report (2014) http://european-biogas. eu/2014/12/16/4331/ (retrieved: 09 Mar. 2016)

European Commission (2008) Regional Biotechnology: Establishing performance indicators for bioclusters and bioregions relevant to the KBBE area.

European Feed Manufacturers'Federation FEFAC http://www.fefac. eu/home.aspx (retrieved: 07 Mar. 2016)

European Patent Office http://www.epo.org/about-us/annual-reports-statistics/statistics.html\#national (retrieved: 20 Mar. 2016)
European Regulatory Office http://www.ure.gov.pl/ (retrieved: 05 Mar. 2016)

Eurostat http://ec.europa.eu/eurostat/web/main/home (retrieved: 08 Mar. 2016)

Gołębiewski J, (2015) Bioeconomy in Poland: Condition and potential for development of the biomass market. Materials from 150th Seminar - European Association of Agricultural Economists.

HFFA Research Paper 03/2016, The economic, social and environmental value of plant breeding in the European Union.

Małyska A, Twardowski T (2011) Opinia publiczna o biotechnologii w Polsce i innych krajach Unii Europejskiej. Nauka 1: 85-99 (in Polish).

Małyska A, Filipiak M, Twardowski T (2013) Opinia ekspertów o agrobiotechnologii. Nauka 1: 149-160 (in Polish).

Polacy wobec GMO, TNS PENTOR (2012) (in Polish)

Polish government's Framework Position Paper on GMO, http://gis. gov.pl/images/bz/gmo/gmo_7.pdf (retrieved: 15 Mar 2016)

Polish Information and Foreign Investment Agency (PAIiIZ) http:// www.paiz.gov.pl/pl [retrieved: 09 Mar. 2016]

Polish Patent Office http://www.uprp.pl/ (retrieved: 20 Mar. 2016)

Position paper concerning biotechnology legislation in Poland, Committee of Biotechnology, Science 1/2015, 183-185.

ProLegu Project www.prolegumes.eu (retrieved: 20 Mar. 2016)

The Grain and Feed Chamber http://www.izbozpasz.pl/home.html (retrieved: 10 Mar. 2016)

The Committee of Biotechnology http://www.kbiotech.pan.pl/ (retrieved: 20 Mar. 2016) 